J. Clin. Chem. Clin. Biochem.

Vol. 20, 1982, pp. 461-463.

\title{
A Modified Kit Method and a Miniphotometer used for the Rapid Determination of Total Bilirubin in Neonatal Sera')
}

\author{
By C. H. Konings
}

Dept. of Clinical Chemistry, Free University Hospital Amsterdam, The Netherlands

(Received October 5, 1981/February 15, 1982)

Summary: The results of the determination of total bilirubin in neonatal sera using the Compur kit and miniphotometer are reported. The kit method was modified somewhat by halving the volume of serum. This smaller volume $(10 \mu \mathrm{l})$ minimizes the interference of haemoglobin and turbidity. In a study of 68 neonatal sera, the method correlated excellently with the assay according to Hertz et al. ((1974) Scand. J. Clin. Lab. Invest. 33, 215-230) and precision was better than $3.5 \%$. The method described is rapid and reliable and ideally-suited for emergency requests for monitoring neonatal hyperbilinubinaemia.

\section{Erfahrungen mit einem modifizierten Fertigtest und Miniphotometer zur Bestimmung des Gesamt-Bilirubins bei Neugeborenen}

Zusammenfassung: Es wird über die Bestimmung des Gesamt-Bilirubins bei Neugeborenen mit dem Compur-Fertigtest und Miniphotometer berichtet. Das Verfahren wird modifiziert, indem das Probenvolumen auf die Hälfte reduziert wurde, was zugleich die Störung durch Hämoglobin und Trübung verringert. Die Bestimmung von Gesamt-Bilirubin im Serum von 68 Neugeborenen korreliert in hohen Ausmaß mit dem Test nach Hertz et al. ((1974) Scand. J. Clin. Lab. Invest. 33, 215-230) und die Präzision war etwa 3.5\%. Die beschriebene Methode führt schnell zu zuverlässigen Ergebnissen und ist als Schnelltest zur laufenden Beobachtung des Icterus neonatorum gut geeignet.

\section{Introduction}

In our laboratory, total bilinubin is determined regularly and routinely in the sera of newborns, because this parameter is still used to monitor the risk of kernicterus (1, 2). Our standard method for serial analysis is a JendrassikGrof procedure with the centrifugal analyzer, but we i prefer a manual test for emergency requests.

Recently, kits for analysis of some blood constituents have been marketed by Compur-Electronic $\mathrm{GmbH}$, München (3). The present paper describes our experience in paediatric clinical chemistry, using the kit designed for the determination of total bilirubin in serum or plasma with the special Compur miniphotometer.

The accuracy and precision of this method, using only half the prescribed sample volume, are discussed and compared with the direct spectrometer method of Hertz (4).

1) Reported in part at the First Joint Meeting of the British, German and Dutch Societies for Clinical Chemistry in Noordwijkerhout, April 1981.

\section{Materials and Methods}

\section{Equipment}

The Compur M 1001 is a pocked-sized photometer provided with an interference filter for measurements at $510 \mathrm{~nm}$. The instrument accepts the disposable cuvettes packed in the Compur kits. The manufacturer has calibrated the four reading scales of the photometer (for cholesterol, glucose, total bilirubin and total protein methods) in SI units and used serial dilutions of a bilirubin enriched control serum from Boehringer, Mannheim (5) to standardize the total bilirubin method. Linearity of the photometer was checked with cobalt(II)sulfate solutions and was found to be full scale.

The spectrophotometer of the GemSAEC centrifugal analyzer (Electro Nucleonics Europe, Breda) was used to read the absorbances of the diluted serum in the method of Hertz et al. The instrument was checked regularly with respect to wavelength and absorbance.

Calibrated SMI pipettes (Scientific Manufacturing Industries, Emeryville) and a Micromedic pump were used on the GemSAEC rotoloader.

\section{Materials}

The Compur Instant M kit for 24 determinations of total bilirubin was purchased from Zeiss Nederland b.v. The kit contains end-to-end calibrated capillaries for dispensing $20 \mu \mathrm{l}$ of plasma or serum, capillaries filled with 2,5-dichlorphenyldiazoniumchloride and disposable microcuvettes with hydrochloric acid and Triton-X. The cuvettes serve both for the reaction and the absorbance measurement. The kit methodology is based on the 
work of Wahlefeld et al. (6). As outlined in Methods, we did not use the $20 \mu$ ld dispensing capillaries.

Commercial control sera Autonorm, Bilirubin Control and Wellcomtrol Three were from Nyegaard \& Co, Dade and Wellcome Reagents Ltd. resp. All other materials were from Merck \& Co.

Blood samples from hyperbilirubinaemic newborns with or without phototherapy were collected on clinical indications by heelprick.

Methods

The instructions in the manual of the Compur kit were altered as follows: serum or plasma volume was $10 \mu \mathrm{l}$ instead of the prescribed $20 \mu \mathrm{l}$; reaction time was 7-10 min (manual: 3$10 \mathrm{~min}$ ), which appears to be more suitable for high bilirubin values.

In summary, the determination of total bilirubin is as follows. Open the microcuvettes by breaking off the nipple on the cap. Add $10 \mu$ l of sample with the SMI pipette to the cuvette. Mix the contents of the cuvette and read the (serum) blank value on the total bilirubin scale as "apparent" bilirubin in $\mu \mathrm{mol} / \mathrm{l}$. Inser the reagent capillary and shake the cuvette in vertical direction for about $10 \mathrm{~s}$. Perform the second measurement after 7-10 min.

Multiply the difference of the two numerical values (in $\mu \mathrm{mol} / \mathrm{l}$ ) by two, to obtain the "true" total bilirubin concentration in the sample (the factor 2 is necessary in this procedure because we used half the volume ò serum for which the scale has been calibrated by the manufacturer).

We reduced the serum and buffer volumes used in the comparison method to $1 / 5$ of the described volumes (4). The distribution disc of GemSAEC was loaded both with serum (use SMI pipet) and buffer (use Micromedic pump) in the same cavity. Absorbances at 466 and $522 \mathrm{~nm}$ were recorded and used to compute the total bilirubin concentration.

The bilirubin control was dissolved in $2.5 \mathrm{ml}$ of water to obtain a solution which contained $420 \mu \mathrm{mol}$ of (unconjugated) bilirubin per liter and human albumin $(66 \mathrm{~g} / 1)$. Other control sera ivere used directly after reconstitution or after storage at $-20^{\circ} \mathrm{C}$ for a few days. Both human sera and control sera were carefully excluded from light before analysis.

Methods were compared by linear regression with correction for experimental error of both methods according to Deming, using the equations given by Cornbleet \& Gochman (7).

\section{Results}

Serial dilutions of Bilirubin Control (see Methods) were prepared and analysed to check the linearity of the presented method. Figure 1 shows that the method is linear up to at least $420 \mu \mathrm{mol} / 1$, the highest concentration tested.

The precision was evaluated by using control sera with a low and high level of total bilirubin. Sera were analysed on 20 consecutive days by three technicians. The data (tab. 1) attest to the good precision of the method even in comparison with the method of Hertz.

In a recent survey (8) organized in the Rotterdam area, it appeared that the Hertz technique gave more precise results than other well-known methods. Moreover, if a good spectrophotometer setting and sample dilution is used, this procedure is regarded as a "reference" method for the analysis of total bilirubin in newborn sera. Therefore, we simultaneously performed a split-sample comparison, using 68 sera from newborns, some of whom had received phototherapy. The clear sera, considered to be nonhaemolysed by visual inspection, were analysed

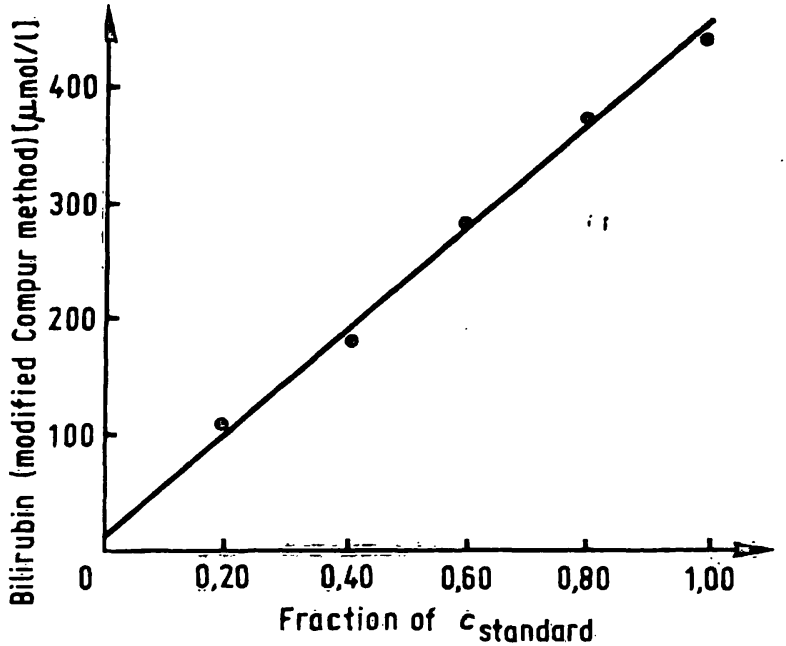

Fig. 1. Calibration graph of the modified Compur method. The standard was a solution of bilirubin and human albumin Serial dịlutions were analysed in trịplicate.

on several separate days. The linear regression relating the two methods is shown in figure 2 . The results demonstrate acceptable agreement with almost identical mean values for the Hertz and modified Compur method (199 and $200 \mu \mathrm{mol} / 1$ resp.). Recovery was assesssed by mixing human sera having different concentrations for total bilirubin (170 and $325 \mu \mathrm{mol} / \mathrm{l})$ and appeared to be better than $98 \%$ in all experiments.

We investigated the effect of haemoglobin by adding different amounts of aqueous dilutions of haemolysate to solutions of Bilirubin Control to give haemogglobin concentrations of 50 to $340 \mu \mathrm{mol} / 1$. There was a $3 \%$ decrease in total bilirubin concentration in the lower region of the linearity curve when a solution containing $125 \mu \mathrm{mol}$ of bilirubin and $100 \mu \mathrm{mol}$ of haemoglobin per liter was assayed, but no influence could be detected with $325 \mu \mathrm{mol}$ bilirubin per liter. Both low and high total bilirubin values were (more) affected by $200-$ $350 \mu \mathrm{mol}$ of haemoglobin per liter in the test solution, the average decrease being $10 \%$. However, such grossly haemolyzed specimens are unknown in our laboratory.

Tab. 1. Precision data, day-to-day precision, $\mathrm{n}=20$.

\begin{tabular}{llllll}
\hline Method & \multirow{2}{*}{$\begin{array}{l}\text { Sample } \\
\text { volume }\end{array}$} & \multicolumn{2}{c}{ Low value } & \multicolumn{2}{c}{ High value } \\
& $(\mu \mathrm{l})$ & $(\mu \mathrm{mol} / 1)$ & $(\%)$ & $(\mu \mathrm{mol} / 1)$ & $(\%)$ \\
\hline Hertz et al. $(4)$ & 10 & 164 & 3.1 & 430 & 2.7 \\
mod. Compur & 10 & 125 & 2.7 & 352 & 3.3 \\
\hline
\end{tabular}

Turbidity is another factor to be considered because the laboratory often analyses specimens from newborns receiving intravenous infusion of Intralipid. Therefore, turbid samples were prepared by adding Intralipid to control sera, but no interference could be detected with concentrations of $2 \mathrm{~g} / 1$ in the samples.

Also heparin, present in the usual concentrations, did not influence the test results.
: 


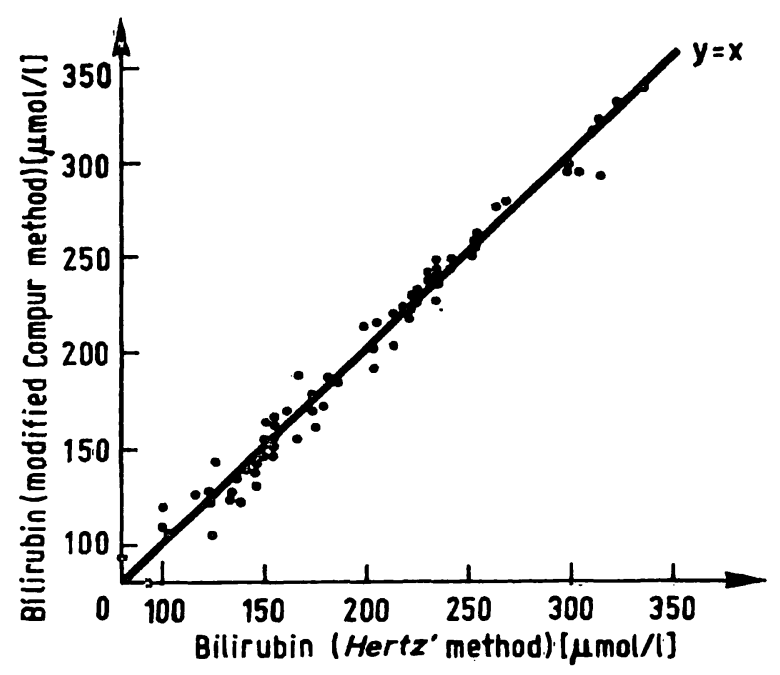

Fig. 2. Comparison of the modified Compur (y-axis) and the Hertz (x-axis) method for neonatal sera. Total bilirubin values, obtained by a single assay with each method, ranged from 100 to $339 \mu \mathrm{mol} / 1$. Slope $=0.99$, intercept $=2$ and correlation coefficient $=0.998$. Standard error of the estimate $=7 \mu \mathrm{mol} / 1$.

\section{Discussion}

In preliminary experiments, analysing $20 \mu \mathrm{l}$ of serum according to the instructions of the manufacturer of the kit, we sometimes measured high serum blank values perhaps due to the presence of haemoglobin in the sample. As the highest concentration which can be read on the scale of the photometer is $430 \mu \mathrm{mol}$ of total bilirubin per liter, high blank readings limit the measurement of the "true" total bilirubin level. Thus concentrations greater than about $300 \mu \mathrm{mol}$ bilirubin per liter could sometimes not be measured as a result of the high blank. Because haemoglobin is frequently encountered in neonatal specimens obtained from capillary blood collection, we decided to base our study on the use of only $10 \mu \mathrm{l}$ of serum. With this sample volume we obtain a lower absolute amount of haemoglobin in the final test solution which will in most cases no longer influence the measurement of total bilirubin (see results). Finally we agree with the idea that blood vol= umes to be sampled from neonates and especially from low-birth weight infants must be as small as possible (9). Blood collection in a haematocrit capillary is a simple way tó collect such small samples.

\section{References}

1. Blumenfeld, T. A. (1981) in Pediatric Clinical Chemistry (Meites, S. ed.) 2. ed., 123, American Association for Clinical Chemistry, Washington.

2. Brodersen, R. (1980) J. Pediatr. 96, 349-356.

3. Wehling, K. \& Frank, G. (1979) in Abstracts of the 3rd. European Congress of Clinical Chemistry, Brighton.

4. Hertz, H., Dybkaer, R. \& Lauritzen, M. (1974) Scand. J. Clin. Lab. Invest. 33, 215-230.

5. Retzer, E. (1980) Personal communication, Compur Electronic GmbH, München.

6. Wahlefeld, A. W., Herz, G. \& Bernt, E. (1972) Scand. J. Clin. Lab. Invest. 29, suppl. 126, Abstract 11.12.
Recently, Barret et al. (10) published desirable analytical performances (CV \%) for some blood constituents. These CV's, set by a group of Australian clinicans, were compared by the authors with previous published data. The desired performances for total bilirubin analysis at the level of $300 \mu \mathrm{mol} / 1$ differ somewhat and were 6.0 , 7.4 and $2.4 \%$ resp., but we believe that the latter figure represents a level of reproducibility that is greater than present methods can provide on a single total bilirubin analysis. Thus the imprecision of the modified Compur method can satisfy clinical criteria. The test shows a good correlation (fig. 2) with the method of Hertz; this proves that the calibration of the photometer in the factory with a commercial bilirubin enriched control serum is acceptable. However, it must be stated that results with low values e.g. $<100 \mu \mathrm{mol} / 1$, are not quite reliable with the presented method. We have omitted these concentrations in the correlation study because they are rather unimportant in the newborn period.

The price of a single test is somewhat high (about 3.- Dfl); the reagents used in the Hertz method are less expensive but a good spectrophotometer is required. The Compur miniphotometer is moderately priced (about 1300.-Dfl) and easy to operate. It must be mentioned that accurate total bilirubin concentrations are dependent on correct standardisation of the method and calibration of the photometer in the factory (see Materials and Methods). Thus every photometer has to be checked at regular intervals to safeguard the accuracy of results.

The acceptability of the presented method by the technicians is good; we have now analysed several hundred patient samples over a period of one year, and the results have been fully satisfactory.

We believe that the method is an excellent alternative to the analysis of total bilirubin with the so called "bilirubinometers", because significant proportional bias (11) and imprecise results (8) have been noticed with some instruments.

\section{Acknowledgement}

Many thanks are due to ir. C. Jakobs for helpful criticism of the manuscript.

7. Cornbleet, P. J. \& Gochman, N. (1979) Clin. Chem. 25, 432-438.

8. Blijenberg, B. G. \& Leijnse, B. (1980) This Journal 18, $27-30$.

9. Nex $\phi$, E., Christensen, N. C. \& Olesen, H. (1981) Clin. Chem. 27, 759-761.

10. Barret, A. E., Cameron, S. J., Fraser, C. G., Penderthy, L. A. \& Shand, K. L. (1979) J. Clin. Pathol. 32, 893-896.

11. Chan, D. W., Rock, R. C. \& Wiegand, N. J. (1979) Clin. Biochem. 12, 184-185.

Drs. C. H. Konings

Acad. Ziekenhuis Vrije Universiteit dc Boelelaan 1117

NL-1081 HV Amsterdan 
